\title{
THE ROLE OF FINANCIAL DEVELOPMENT ON FOREIGN DIRECT INVESTMENT IN ASEAN-5 COUNTRIES: PANEL COINTEGRATION WITH CROSS-SECTIONAL DEPENDENCY ANALYSIS
}

\author{
Elya Nabila Abdul Bahri ${ }^{1,3^{*}}$, Abu Hassan Shaari Md Nor ${ }^{1}$ and Nor Hakimah Haji \\ Mohd Nor ${ }^{2}$
}

${ }^{1}$ School of Economics, Faculty of Economics and Management, Universiti Kebangsaan Malaysia, 43600 UKM Bangi, Selangor, Malaysia

${ }^{2}$ Faculty of Management and Muamalah, Kolej Universiti Islam Antarabangsa

Selangor, Bandar Seri Putra, 43000 Kajang, Selangor, Malaysia

${ }^{3}$ Faculty of Business, Finance and Hospitality, MAHSA University, Jalan SP 2, Bandar Saujana Putra, 42610 Jenjarum, Selangor, Malaysia

*Corresponding author: elyanabila@siswa.ukm.edu.my, elyanabila@gmail.com

\begin{abstract}
This paper investigates the impact of the financial development on foreign direct investment (FDI) inflows in ASEAN-5 countries over the period of 1980-2013. The 5 countries included in this study are Malaysia, Thailand, Indonesia, Singapore and Philippines. In the model, financial development, consumer price index (CPI) and real gross domestic product (GDP) per capita are the independent variables. The stationarity of the variables is examined through both first-and second-generation unit root tests with the cross-sectional dependence among countries. The Pedroni and Westerlund cointegration tests results show the existence of long run relationship among the variables. Long term coefficients are estimated using Fully Modified Ordinary Least Square (FMOLS) model and it reveals that financial development has a nonlinear relation with FDI. When financial development passes the threshold point at above 70 point, it will benefit the FDI. Furthermore, the Panel Vector Error Correction Model (VECM) is applied to examine the causality relationship among the associated variables. The causality analysis confirms the presence of both long-
\end{abstract}

Publication date: 15 August 2018

To cite this article: Bahri, E. N. A., Nor, A. H. S. M., \& Nor, N. H. H. M. (2018). The role of financial development on foreign direct investment in ASEAN-5 countries: Panel cointegration with crosssectional dependency analysis. Asian Academy of Management Journal of Accounting and Finance 14(1), 1-23. https://doi.org/10.21315/aamjaf2018.14.1.1

To link to this article: https://doi.org/10.21315/aamjaf2018.14.1.1

(C) Asian Academy of Management and Penerbit Universiti Sains Malaysia, 2018. This work is licensed under the terms of the Creative Commons Attribution (CC BY) (http://creativecommons. org/licenses/by/4.0/). 
term relationship and short term dynamic among the FDI, financial development, CPI and real GDP per capita.

Keywords: foreign direct investment, financial development, panel cointegration secondgeneration, cross-sectional dependence, nonlinear

\section{INTRODUCTION}

Following the financial liberalisation attempt, especially during the 1990s, foreign direct investment (FDI) has become an increasingly important element for economic development and integration of developing countries and transition economies (Çeviș \& Çamurdan, 2007), including the ASEAN-5 countries. The creation of ASEAN Economic Community (AEC) at the Ninth ASEAN Summit in October 2003 represented an important milestone in ASEAN economic cooperation. It stimulated FDI inflows by reducing business costs associated with multinational activities in the ASEAN region has always been a primary objective of the economic cooperation (Plummer \& Cheong, 2009). Creating a more stable economic condition and strengthening the financial sector may establish an attractive business environment for multinational firms to invest in the ASEAN-5 region.

According to Levine (2005), growing evidence shows that financial institutions and financial markets can exert a strong influence on economic development, where economic growth will affect the FDI performance. Alfaro, Kalemli-Ozcan and Sayek (2009) provide evidence that financial markets act as a channel in facilitating the positive traits of FDI performance to be realised. Levine (2005) provides detailed discussion on the five major functions of a financial system: producing information and allocating capital; monitoring firms and implementing corporate governance; ameliorating risk; pooling the savings; and easing exchange, all of which contribute towards stimulating economic growth. Financial development is discovered as an assistance to the FDI where their benefits of financial liberalisation could contribute to the FDI of the recipient countries. Thus, financial development is shown to be important to promote FDI performance. Recent empirical literature has brought forth the assertion that financial development is a key explanation for FDI performance. Financial development is found to serve as a determinant that enables the efficiency of FDI performance. The burgeoning past literature has examined the role of financial development on FDI to promote the economic growth but the literature that investigates the role of financial development on FDI performance has been scarce. Financial development is recognised as an important absorptive capacity 
due to its major functions in the country's financial system that includes both banking and stock market sectors.

With this background of studies, our study has been done extensively to explore the impact of the financial development on FDI in nonlinear relationships, using an advanced econometric technique. We explore the nature of the relationship between the financial development and FDI, whether or not it may in fact be nonmonotonic. In previous studies, the impact of the financial development on FDI in linear specification may be inaccurate. Furthermore, this study investigates the relationship between financial development, Consumer Price Index (CPI) and economic growth with FDI performance using the panel cointegration analysis for a sample of ASEAN-5 countries over a period of 1980 to 2013 by considering the cross-sectional dependency and nonlinear relationship in the long run estimation.

\section{LITERATURE REVIEW}

Early theories of the determinants of FDI were encompassed in eclectic approach by Dunning and Robson (1988). Three key requirements for FDI highlighted by them were, firstly, the firm must possess stable specific advantages; secondly, the firm must find it beneficial to utilise these advantages directly instead of selling or leasing them, the so called internalisation advantages; and lastly, the firm must find it profitable to combine these advantages with at least one factor input abroad so that local production dominates exporting or locational advantages. These advantages include proximity to markets, specialised suppliers, evasion of protective barriers, and factor endowment advantages.

The recent empirical literature has brought forth the assertion that financial development is the determinant of FDI performance. However, most of past literature focus on the impact of financial development on FDI performance using the linear model. Before we proceed for further discussion, it is important to understand about the determinant of FDI inflows. Then, the determinants can be tested whether or not there is an existence of co-movement between the variables with FDI inflows.

Blonigen and Piger (2014) listed 56 determinants of FDI. One of the determinants is host country financial infrastructure which uses the domestic credit to private sector. Sankaran (2015) recognised the financial market as the determinant of FDI inflows. The financial markets are measured by the domestic credit provided by banks and domestic credit provided to the private sector as a percentage of Gross Domestic Product (GDP) is used. Domestic credit to the private sector refers to financial resources provided to the private sector through 
loans, purchases of non-equity securities, and trade credits and other receivable accounts. Domestic credit provided by banks is nonguaranteed long-term commercial bank loans from private banks and other private financial institutions. The investors need the information of financial health of the host countries. Thus, financial information quality also affected the investment efficiency (Rad, Embong, Mohd-Saleh, \& Jaffar, 2016).

Mohamed and Sidiropoulos (2010) examined the financial development as determinants of FDI in Middle East and North Africa (MENA) countries. Financial development is measured through the weighted average of liquid liabilities, credit to the private sector and credit by banks to the private sector. Alfaro, Chanda, Kalemli-Ozcan and Sayek (2004) investigated the impact of the financial market development on the FDI attraction to achieve economic development for the period of 1975 to 1995. The research suggested that the development of strong financial market can increase an economy's ability to absorb and efficiently manage FDI capital inflow and take advantage of potential FDI benefits. Meanwhile, the study from Benáček, Lenihan, Andreosso-O'Callaghan, Michaliková and Kan (2014) used the financial freedom as one of the FDI inflows determinants. Financial freedom is a measure of banking security as well as independence from government control. The state ownership of banks and other financial institutions is seen as an inefficient burden, and political favouritism has no place in a free capital market. Sawalha, Mazouz and Pellet (2013) also found financial capital to be one of the FDI inflows determinants.

Macroeconomic sources have been identified as factors that influence FDI performance. This hypothesis has been tested by numerous studies (see, for examples Bekana, 2016; Pattayat, 2016; Dauti, 2015; Henry, Saadatmand, \& Toma, 2015; Sawalha et al., 2013; Zulfiu, 2008; Mateev, 2009; Johnson, 2006). The study from Zulfiu (2008) employs the determinant of FDI inflows using static and dynamic panel. Meanwhile Mateev (2009) found that gravity factors (GDP, population, distance and cultural proximity) and cost and transition specific factors (wages, corruption and risk credit rating) are statistically significant with the estimated sign expected which affects the FDI inflows. The work by Johnson (2006) using panel data into a CEE sample found that the proxies for host country demand have a significant positive effect on the FDI. The result suggested that market seeking (absolute GDP, GDP per capita) is an important motive for investment in the CEE economies.

Although recent studies discover that financial development influences FDI performance to be realised, the long run relationship between the variables including FDI, financial development and macroeconomic variable have not 
been adequately addressed in the existing studies. Therefore, this paper attempts to contribute to the existing literature in the different dimensions. This study investigates the effects of the financial development on the FDI performance which employed both the linear and quadratic models. Quadratic model is used due to the nonlinear relationship between financial development and economic growth in the recent literature such as Law and Singh (2014) and Samargandi, Fidrmuc and Ghosh (2015). However, in this study, the impact of the financial development on the FDI performance will be investigated. This study also examines the long run relationship between FDI, financial development and macroeconomic sources using the panel cointegration first- and second-generation analyses for a sample of ASEAN-5 countries over the from period 1980 to 2013.

Thus, this study extends the existing literature with two main contributions. Firstly, we examine the nonlinear relationship between the financial development on the FDI. The nonlinear relationship between financial development and FDI is lacking in the existing literature. The study by Law and Singh (2014) and Samargandi et al. (2015) on the relationship between financial development on economic growth stresses that it is nonlinear. Therefore, we are interested in scrutinising the financial development relationship on FDI inflows in both linear and nonlinear models. Secondly, we investigate the co-movement of FDI, financial development and macroeconomic sources by considering the cross-sectional dependency using the second-generation or Westerlund's (2007) cointegration test. The previous analysis using the panel cointegration firstgeneration assumes that all individual cross sections are independent. In the case of our study, the cross-sectional dependency may exist in ASEAN-5 countries influenced by economic integration, financial openness, economic freedom and spillover effects.

\section{ECONOMETRIC MODEL AND DATA DESCRIPTION}

To investigate the effect of the financial development (FinDev), inflation (INF) and gross domestic product per capita $(G D P)$ on foreign direct investment $(F D I)$, the econometric model of this study is based on the studies undertaken by Alfaro et al. (2004; 2009) and Blonigen and Piger (2014) which can be modified and specified as follows:

$$
\begin{aligned}
& F D I_{i t}=f\left(\text { FinDev }_{i t}, C P I_{i t}, G D P_{i t}, w_{i}\right) \\
& F D I_{i t}=\alpha_{0}+\alpha_{1 i} \text { FinDev }_{i t}+\alpha_{2 i} C P I_{i t}+\alpha_{3 i} G D P_{i t}+w_{i}+u_{i t}
\end{aligned}
$$


The model uses a linear specification in Equation (2), and the crosssections are denoted by subscript $i(i=1,2, \ldots, N)$ and time period by subscript $t$ $(t=1,2, \ldots, T), w$ is the country fixed effect and $u$ is the stochastic random term. Following Law and Singh (2014), the domestic credit to private sector by banks as a percentage share of GDP and private sector credit to deposit money are used as proxies for financial development (FinDev). The model incorporates consumer price index $(C P I)$ and gross domestic product $(G D P)$ as controlled variables. We extend the previous study by using the quadratic model in the specification of the FDI determinant as follows:

$$
F D I_{i t}=\alpha_{0}+\alpha_{1 i} \text { FinDev }_{i t}+\alpha_{2 i} \text { FinDev }_{i t}^{2}+\alpha_{3 i} C I_{i t}+\alpha_{4 i} G D P_{i t}+w_{i}+u_{i t}
$$

where FinDev $^{2}{ }_{i t}$ indicates the nonlinear relation between financial development and FDI inflows. In Equation (3), $\alpha_{0}$ is intercept, $\alpha_{1}, \alpha_{2}, \alpha_{3}$ and $\alpha_{4}$ are the parameters' slopes to be estimated. $\alpha_{3}$ is expected to be negative since higher inflation will harm FDI performance due to the increase in the cost of production, while $\alpha_{4}$ is expected to be positive because the GDP is an important factor of investment. The focal parameters in the model are $\alpha_{1}$ and $\alpha_{2}$. If there exists a nonlinear relationship between financial development and FDI, we expect the anti-Kuznet curve since higher financial development will assist FDI to perform better. Anti-Kuznet curve is verified by $\alpha_{1}$ being significantly negative and $\alpha_{2}$ significantly positive. The threshold point is based on first order condition (dFDI/ $\mathrm{dFinDev}$ ). Based on Equation (3), the financial development turning point can be estimated as $-\alpha_{1} / 2 \alpha_{2}$.

This study uses FDI inflows as the percentage of GDP. Real GDP per capita in constant US dollar (US\$) is used to measure economic growth. Domestic credit to private sector by banks as a percentage share of GDP (DCPS) and private credit to deposit money $(P C D M)$ are used as proxies for financial development, and each proxy is employed in FinDev ${ }_{i t}$ as Model 1 and Model 2 respectively. Five countries have been selected among the ASEAN countries for the estimation of the econometric model on the basis of data availability and balanced panel data are used. Our sample focused on ASEAN-5 countries including Malaysia, Singapore, Thailand, Indonesia, and the Philippines. The study covers 34 years for the period of 1980-2013. All data are obtained from 2015 World Development Indicators of the World Bank, UNCTAD Database and Financial Structure Dataset.

The last few decades have witnessed an increasing economic and financial integration of countries comprised in ASEAN-5 economy, which implies a strong interdependence between countries. Testing for cross-sectional dependence is crucial in determining panel data estimations. Therefore, the Pesaran (2004) test for cross-sectional dependence (CD test) is employed for all variables. 
The empirical result is reported in Table 1, which indicates that cross-sectional independence can be rejected for all variables. As shown in Table 1, among the variables, the real GDP per capita shows the highest cross-sectional dependence where the Pesaran CD statistics is 15.997 . Hence, in this study we consider the cross-sectional dependence among countries in ASEAN-5 by using Westerlund's cointegration test as the second-generation of panel cointegration. In addition, the Fully Modified OLS (FMOLS) is used to estimate the long run coefficient in the specification. Panel vector error correction model (VECM) and causality test are used to investigate the direction of causality among the variables.

Table 2 presents the mean of all variables of each country in the ASEAN-5 economies. As shown in this table, there is a considerable variation in real GDP per capita across these countries, ranging from as low as US\$1,058.48 in Indonesia to as high as US\$22,300.00 in Singapore. The financial development demonstrates that Malaysia is consistently the highest while Indonesia is consistently the lowest for all proxies, DCPS and PCDM. Descriptive statistics of the variables are shown in Table 3. Jarque Bera for normality test shows that all variables are not normally distributed. The median for DCPS and PCDM is 74\% and 68\%, respectively. The correlation matrix presented in Table 4 reveals that the correlations among the variables are low, with the highest at 0.99 between domestic credit to private sector and private credit to deposit money.

Table 1

Result of Pesaran (2004) cross-section dependence test

\begin{tabular}{lcc}
\hline Variable & Pesaran (2004) CD Test & Breusch-Pagan LM test \\
\hline Foreign direct investment inflows & $4.404 * * *$ & $30.368 * * *$ \\
Domestic credit to private sector & $9.598^{* * * *}$ & $113.829 * * *$ \\
Private credit by deposit money & $10.034 * * *$ & $120.894 * * *$ \\
Consumer price index & $17.984 * * *$ & $323.499 * * *$ \\
Real GDP per capita & $15.997 * * *$ & $263.607 * * *$ \\
\hline
\end{tabular}

Notes: (i) The null hypothesis of CD test is cross section independence, $\mathrm{CD} \sim \mathrm{N}(0.1)$.

(ii) $* * *$ denotes significant at $1 \%$ level. 
Elya Nabila Abdul Bahri et al.

Table 2

Mean of variables over 1980-2013 for each country

\begin{tabular}{lccccc}
\hline & $\begin{array}{c}\text { Foreign direct } \\
\text { investment } \\
\text { inflows } \\
\text { (\% of GDP) }\end{array}$ & $\begin{array}{c}\text { Domestic credit } \\
\text { to private sector } \\
\text { (\% of GDP) }\end{array}$ & $\begin{array}{c}\text { Private credit } \\
\text { by deposit } \\
\text { money banks } \\
\text { (\% of GDP) }\end{array}$ & $\begin{array}{c}\text { Consumer } \\
\text { price index }\end{array}$ & $\begin{array}{c}\text { Real GDP } \\
\text { per capita } \\
\text { US at 2000 } \\
\text { prices }\end{array}$ \\
\hline Malaysia & 8.992 & 103.944 & 98.856 & 72.882 & $4,365.341$ \\
Indonesia & 3.066 & 29.876 & 27.617 & 41.683 & $1,058.476$ \\
Thailand & 5.830 & 94.959 & 90.829 & 68.011 & $2,062.662$ \\
Singapore & 27.287 & 91.526 & 87.402 & 81.843 & $22,300.000$ \\
Philippine & 3.455 & 30.328 & 27.782 & 53.297 & $1,117.028$ \\
\hline
\end{tabular}

Table 3

Descriptive statistics of variables

\begin{tabular}{lccccc}
\hline Descriptive statistics & FDI & DCPS & PCDM & CPI & GDP \\
\hline Mean & 9.726 & 70.127 & 66.497 & 63.483 & $6,180.702$ \\
Median & 5.617 & 73.651 & 68.378 & 67.086 & $2,155.881$ \\
Maximum & 54.042 & 165.719 & 165.860 & 116.910 & $37,491.080$ \\
Minimum & 1.000 & 8.853 & 8.000 & 5.554 & 548.404 \\
Standard deviation & 10.663 & 39.040 & 38.075 & 29.768 & $9,025.840$ \\
Skewness & 2.024 & 0.211 & 0.265 & -0.364 & 2.013 \\
$\quad$ Kurtosis & 6.911 & 1.959 & 2.036 & 2.158 & 5.954 \\
Jarque-Bera & 224.467 & 8.939 & 8.574 & 8.773 & 176.556 \\
$\quad$ Probability & 0.000 & 0.0115 & 0.014 & 0.012 & 0.000 \\
Minimum & 1.000 & 8.853 & 8.000 & 5.554 & 548.404 \\
25\% quantile & 2.850 & 32.241 & 28.886 & 42.944 & $1,080.409$ \\
Median & 5.617 & 73.651 & 68.378 & 67.086 & $2,155.881$ \\
$75 \%$ quantile & 11.071 & 100.727 & 97.277 & 85.772 & $5,564.186$ \\
Maximum & 54.042 & 165.719 & 165.860 & 116.910 & $37,491.080$ \\
\hline
\end{tabular}

Notes: FDI $=$ foreign direct investment; DCPS $=$ domestic credit to private sector; $\mathrm{PCDM}=$ private credit by deposit money banks; CPI = consumer price index; GDP = real GDP per capita. 
Table 4

Correlations of variables

\begin{tabular}{lccccc}
\hline Correlations & FDI & DCPS & PCDM & CPI & GDP \\
\hline FDI & 1.000 & & & & \\
DCPS & 0.651 & 1.000 & & & \\
PCDM & 0.643 & 0.994 & 1.000 & & \\
CPI & 0.567 & 0.587 & 0.596 & 1.000 & \\
GDP & 0.856 & 0.678 & 0.683 & 0.587 & 1.000 \\
\hline
\end{tabular}

Notes: FDI = foreign direct investment; DCPS $=$ domestic credit to private sector; $\mathrm{PCDM}=$ private credit to deposit money by banks; INF = inflation; GDP = real GDP per capita

\section{METHODOLOGY}

\section{Panel Unit Roots}

We apply the IPS (Im, Pesaran, \& Shin, 1997) and MW (Maddala \& Wu, 1999) panel unit root tests to check the stationary properties of the variables. These tests apply to a balanced panel where IPS represents a heterogeneous panel test and MW panel unit root test is a non-parametric test. However, according to Campbell and Perron (1991), the standard unit root and cointegration tests based on individual time series have low statistical power, especially when the time series is short. In contrast, the use of panel unit root test allows for higher degrees of freedom by considering cross sectional dimension (Levin, Lin, \& Chu, 2002).

For the case of ASEAN-5 countries in our study, the common stochastic trends may occur due to global developments or strong relationships between economies, especially when the countries are neighbours or may involve in an integrated process in the economy. According to Pesaran (2004), cross-section dependence can arise for several reasons, such as spatial spillovers, financial contagion, socioeconomic interactions, and common factors. In this study, Pesaran's (2007) unit root test is employed in heterogeneous panels with crosssection dependence for its simplicity and clarity. The standard DF (or ADF) regressions are augmented with the cross-section averages of lagged levels $\left(x_{i t-1}\right)$ and first-differences $\left(\Delta x_{i t-1}\right)$ of the individual series to eliminate cross dependence. Pesaran (2007) obtains a cross-sectionally augmented Dickey-Fuller (CADF) test based on the following model:

$\Delta x_{i t}=\alpha_{i}+\rho x_{i t-1}+v_{i t}$ 
where $v_{i t}=g_{i} \theta_{t}+\mu_{i t} \cdot \theta_{t}$ is a common factor and $\mu_{i t}$ is white noise.

The CADF model is given by, without the autocorrelation of $\mu_{i t}$ :

$\Delta x_{i t}=\alpha_{i}+\rho x_{i t}+c_{i} \bar{x}_{t-1}+d_{i} \Delta \bar{x}_{t-1}+\varepsilon_{i t}$

The Pesaran statistic with the cross-sectionally augmented IPS (CIPS) is given by $\operatorname{CIPS}(N, T)=\frac{1}{N} \sum_{i=1}^{q} t_{i}(N, T)$.

where $t_{i}$ indicates the statistics from each CADF model for each individual $i$ of the panel. The critical values of the statistic are given by Pesaran (2007).

\section{The Panel Cointegration Test}

The cointegration test among the variables of Equation (2) is tested using Pedroni's (1999; 2004) first-generation and Westerlund's (2007) second-generation panel cointegration tests accounting for the cross-sectional dependence. Pedroni uses the following cointegration equation and this is re-written as:

$F D I_{i, t}=\alpha_{\mathrm{i}}+\rho_{i} t+\beta_{1 i} Z_{1 i, t}+\ldots+\beta_{\mathrm{mi}} Z_{m i, t}+u_{i t}$

where $F D I$ and $Z$ are assumed to be integrated of order one. The specific intercept term $\alpha_{\mathrm{i}}$ and slope coefficients $\beta_{1 i}, \beta_{2 i, \ldots,}, \beta_{\mathrm{m} i}$ vary across individual members of the panel. Pedroni $(1999 ; 2004)$ proposed seven different statistics to test for the cointegration relationship in a heterogeneous panel. The seven test statistics of Pedroni are classified into within-dimension and between-dimension statistics. Within-dimension statistics are referred to as panel cointegration statistics, while between-dimension statistics are called group mean panel cointegration statistics.

The second-generation panel cointegration test has four error-correctionbased tests developed by Westerlund (2007), which allows for large degree of heterogeneity, both in the long-run cointegrating relationship and in the shortrun dynamics. The underlying idea is to test for the presence of cointegration by determining whether or not there exists error-correction for individual panel members of for the panel as a whole. Equation (2) can be transformed to the following error-correction model: 
$\Delta F D I_{i t}=c_{1 j}+\varphi_{i 1} \sum_{j=1}^{p} \Delta F D I_{i t-j}+\varphi_{i 2} \sum_{j=0}^{p} \Delta F i n D e v_{i t-j}+$

$\varphi_{i 3} \sum_{j=0}^{p} \Delta C P I_{i t-j}+\varphi_{i 4} \sum_{j=0}^{p} \Delta G D P_{i t-j}+\theta_{i}$

$\left[\beta_{1 i}\left(F D I_{i t-1}\right)-\beta_{2 i}\left(F i n D e v_{i t-1}\right)-\beta_{3 i}\left(C P I_{i t-1}\right)-\beta_{4 i}\left(G D P_{i t-1}\right)\right]$

$+\varepsilon_{i t}$

where $\theta_{i}$ measures the speed of error-correction towards the long run equilibrium $F D I_{i t}=\left(\varphi_{i} / \theta_{i}\right) \times x_{i t}$ for that series $i$. The $G_{\alpha}$ and $G_{\tau}$ test statistics test $\mathrm{H}_{0}: \theta_{i}=0$ for all $i$ versus $\mathrm{H}_{1}: \theta_{i}<0$ for at least one $i$. These statistics start from a weighted average of the individually estimate of $\theta_{i}$ 's and the $t$-ratio respectively. If $\mathrm{H}_{0}$ is rejected, it means that cointegration exists for at least one of the crosssectional units. While, $P_{\alpha}$ and $P_{\tau}$ test statistics pooled the information over all the cross-sectional units to test $\mathrm{H}_{0}: \theta_{i}=0$ for all $i$ versus $\mathrm{H}_{1}: \theta_{i}<0$ for all $i$. The rejection of $\mathrm{H}_{0}$ should therefore be taken as evidence of cointegration for the panel as a whole. According to Westerlund (2007), $P_{\alpha}$ and $P_{\tau}$ test statistics have the highest power and are the most robust to cross-sectional correlation.

\section{Long-run Cointegrated Regression Estimation}

If the evidence of cointegration is proven, we proceed with long-run coefficient estimation of FDI determinants (FinDev, CPI and GDP). In the presence of cointegration, OLS estimates do not give efficient results. For this reason, several estimators have been proposed. For example, Kao and Chiang (2000) argue that their parametric panel Dynamic OLS (DOLS) estimator pools the data along the within dimension of the panel. However, the panel DOLS of Kao and Chiang (2001) does not consider the importance of cross-sectional heterogeneity in the alternative hypothesis.

The fully modified OLS (FMOLS) proposed by Pedroni (2000; 2001) that allows for cross-sectional heterogeneity in the alternative hypothesis, endogeneity and serial correlation problems is applied to estimate long-run coefficients in order to obtain consistent and asymptotically unbiased estimates of the cointegrating vectors. The panel FMOLS estimator for the coefficient $\beta$ is defined as:

$$
\begin{aligned}
& \hat{\beta}=N^{-1} \sum_{i=1}^{N}\left[\sum_{t=1}^{T}\left(X_{i t}-\bar{X}_{1}\right)^{2}\right]^{-1}\left[\sum_{t=1}^{T}\left(X_{i t}-\bar{X}_{1}\right) Y_{i t}^{*}-T \hat{\tau}_{i}\right] \\
& \quad \text { where } Y_{i t}^{*}=\left(Y_{i t}-\bar{Y}\right)-\frac{\hat{L}_{21 i}}{\hat{L}_{22 i}} \Delta X_{i t}, \hat{\tau}_{i} \equiv \hat{\Gamma}_{21 i}+\hat{\Omega}_{21 i}^{0}-\frac{\Gamma_{21 i}}{\Gamma_{22 i}}\left(\hat{\Gamma}_{22 i}+\hat{\Omega}_{22 i}^{0}\right) \text { and } \hat{L}_{i}
\end{aligned}
$$

is a lower triangular decomposition of $\hat{\Omega}_{i}$. The associated $t$-statistic is assumed to be normally distributed and give: 
$t_{\hat{\beta}^{*}}=N^{-1 / 2} \sum_{i=1}^{N} t_{\hat{\beta}^{*}}, i$ where $t_{\hat{\beta}^{*}}, i=\left(\hat{\beta}_{i}^{*}-\beta_{0}\right)\left[\hat{\Omega}_{11 i}^{-1} \sum_{t=1}^{T}\left(X_{i t}-\overline{X^{2}}\right)\right]^{1 / 2}$

\section{Panel Vector Error-correction Model}

The panel Granger causality in the framework of the panel VECM is employed to analyse the direction of the causal effect among foreign direct investment, financial development, inflation and real GDP per capita. The panel VECM approach is based on Engle and Granger's (1987) procedure. In the first step, we estimate the long-run model specified in Equation (2) in order to obtain the estimated residuals. Next, we estimate the Granger causality model based on the error-correction model. The empirical model is represented by the following equations:

$$
\begin{gathered}
\Delta F D I_{i t}=\alpha_{1 i}+\sum_{k=1}^{m} \lambda_{11 i k} \Delta F D I_{i, t-k}+\sum_{k=1}^{m} \lambda_{12 i k} \Delta F_{i n D e v_{i, t-k}}+ \\
\sum_{k=1}^{m} \lambda_{13 i k} \Delta C P I_{i, t-k}+\sum_{k=1}^{m} \lambda_{14 i k} \Delta G D P_{i, t-k}+\phi_{1 i} E C_{i, t-1}+\mu_{1 i t} \\
\Delta \text { inDev }_{i t}=\alpha_{2 i}+\sum_{k=1}^{m} \lambda_{21 i k} \Delta F i n D e v_{i, t-k}+\sum_{k=1}^{m} \lambda_{22 i k} \Delta F D I_{i, t-k}+ \\
\sum_{k=1}^{m} \lambda_{23 i k} \Delta C P I_{i, t-k}+\sum_{k=1}^{m} \lambda_{24 i k} \Delta G D P_{i, t-k}+\phi_{2 i} E C_{i, t-1}+\mu_{2 i t} \\
\Delta C P I_{i t}=\alpha_{3 i}+\sum_{k=1}^{m} \lambda_{31 i k} \Delta B a n k_{i, t-k}+\sum_{k=1}^{m} \lambda_{32 i k} \Delta F i n D e v_{i, t-k}+ \\
\sum_{k=1}^{m} \lambda_{33 i k} \Delta F D I_{i, t-k}+\sum_{k=1}^{m} \lambda_{34 i k} \Delta G D P_{i, t-k}+\phi_{3 i} E C_{i, t-1}+\mu_{3 i t} \\
\Delta \ln G D P_{i t}=\alpha_{4 i}+\sum_{k=1}^{m} \lambda_{41 i k} \Delta \ln G D P_{i, t-k}+\sum_{k=1}^{m} \lambda_{42 i k} \Delta \ln F i n D e v_{i, t-k}+ \\
\sum_{k=1}^{m} \lambda_{41 i k} \Delta \ln G D P_{i, t-k}+\sum_{k=1}^{m} \lambda_{43 i k} \Delta \ln C P I_{i, t-k}+ \\
\sum_{k=1}^{m} \lambda_{44 i k} \Delta \ln F D I_{i, t-k}+\phi_{4 i} E C_{i, t-1}+\mu_{4 i t}
\end{gathered}
$$

where FDI is foreign direct investment, FinDev is financial development, $C P I$ is a proxy for inflation and GDP is real GDP per capita, $E C$ is error-correction term comes from the FMOLS estimation, and $m$ is the lag length. The short-run causality is determined by the statistical significance of the $F$-statistic associated with the corresponding right hand side variables. The presence or absence of longrun causality can be established by examining the significance of the $t$-statistic on the coefficient $\phi$, in Equations (11a-11d). 


\section{RESULTS AND DISCUSSION}

The results of the first-generation panel unit root tests at level and first difference are presented in Table 5. These results are obtained by applying the panel unit root test: IPS and MW panel unit root test. The optimal lag length is fixed to lag 1 . The result shows that all variables are stationary at first difference without trend for the first-generation panel unit root. The results of the second-generation panel unit root using Pesaran (2007) with and without trend are presented in Table 6 using two lag orders. The null hypothesis of the unit roots cannot be rejected in level, but rejected in first differences, for all the six variables. Thus, we conclude that all series are integrated of order one or $I(1)$ in the panel of ASEAN-5 countries. Using these results, we proceed to test FDI, DCPS, PC, CPI, and GDP for cointegration to determine if there is a long-run relationship in the econometric specifications (Model 1 and Model 2).

Table 5

First-generation panel unit root tests: Im, Pesaran and Shin (IPS) and Maddala-Wu (MW)

\begin{tabular}{llcccc}
\hline \multirow{2}{*}{ Variables } & Model & IPS & MW & IPS & MW \\
\cline { 3 - 6 } & & \multicolumn{2}{c}{ Level } & First Difference \\
\hline Foreign direct investment & Without trend & -0.31 & 22.27 & $-8.54^{\mathrm{a}}$ & $110.94^{\mathrm{a}}$ \\
& With trend & $-2.35^{\mathrm{a}}$ & $28.99^{\mathrm{a}}$ & $-7.23^{\mathrm{a}}$ & $86.42^{\mathrm{a}}$ \\
Domestic credit to private sector & Without trend & -1.14 & 14.28 & $-4.36^{\mathrm{a}}$ & $44.23^{\mathrm{a}}$ \\
& With trend & -0.08 & 7.36 & $-3.09^{\mathrm{a}}$ & $31.40^{\mathrm{a}}$ \\
Private credit to deposit money & Without trend & -2.18 & 21.26 & $-4.51^{\mathrm{a}}$ & $44.58^{\mathrm{a}}$ \\
& With trend & -1.38 & 15.74 & $-3.18^{\mathrm{a}}$ & $30.22^{\mathrm{a}}$ \\
Consumer price index & Without trend & 1.78 & 8.72 & $-5.26^{\mathrm{a}}$ & $53.89^{\mathrm{a}}$ \\
& With trend & 1.09 & 3.69 & $-5.01^{\mathrm{a}}$ & $53.91^{\mathrm{a}}$ \\
& Without trend & 2.13 & 2.38 & $-5.44^{\mathrm{a}}$ & $60.25^{\mathrm{a}}$ \\
& With trend & 0.67 & 4.48 & $-5.19^{\mathrm{a}}$ & $\mathrm{a}$ \\
\hline
\end{tabular}

Note: ${ }^{a}$ denotes significant at $1 \%$ level. 
Elya Nabila Abdul Bahri et al.

Table 6

Second-generation panel unit root tests: Pesaran (2007) panel unit root test (CIPS)

\begin{tabular}{|c|c|c|c|c|c|c|}
\hline \multirow{2}{*}{ Variable } & \multicolumn{3}{|c|}{ Model without trend } & \multicolumn{3}{|c|}{ Model with trend } \\
\hline & $q=0$ & $q=1$ & $q=2$ & $q=0$ & $q=1$ & $q=2$ \\
\hline \multicolumn{7}{|l|}{ Level } \\
\hline Foreign direct investment & $-4.09^{\mathrm{a}}$ & -1.80 & -0.41 & $-4.01^{\mathrm{a}}$ & -1.69 & -0.95 \\
\hline $\begin{array}{l}\text { Domestic credit to private } \\
\text { sector }\end{array}$ & -1.28 & -0.45 & 0.30 & 0.33 & 1.09 & 1.85 \\
\hline $\begin{array}{l}\text { Private credit to deposit } \\
\text { money }\end{array}$ & -0.78 & -1.60 & -0.15 & 1.33 & 0.01 & 1.62 \\
\hline Consumer price index & 0.89 & -0.58 & -1.88 & 1.98 & 1.01 & 0.09 \\
\hline Real GDP per capita & 1.77 & 0.54 & -0.07 & 4.17 & 2.97 & 2.71 \\
\hline \multicolumn{7}{|l|}{ First Difference } \\
\hline Foreign direct investment & $-10.03^{\mathrm{a}}$ & $-7.72^{\text {a }}$ & $-5.07^{a}$ & $-9.71^{\text {a }}$ & $-6.71^{a}$ & $-3.94^{\mathrm{a}}$ \\
\hline $\begin{array}{l}\text { Domestic credit to private } \\
\text { sector }\end{array}$ & $-8.04^{\mathrm{a}}$ & $-4.60^{a}$ & -0.57 & $-7.45^{\mathrm{a}}$ & $-3.95^{\mathrm{a}}$ & 0.15 \\
\hline $\begin{array}{l}\text { Private credit to deposit } \\
\text { money }\end{array}$ & $-3.66^{a}$ & $-3.55^{\mathrm{a}}$ & -0.83 & $-2.62^{\mathrm{a}}$ & $-3.00^{\mathrm{a}}$ & -0.24 \\
\hline Consumer price index & $-5.43^{a}$ & $-3.43^{\mathrm{a}}$ & -1.67 & $-4.63^{a}$ & $-2.97^{\mathrm{a}}$ & -0.34 \\
\hline Real GDP per capita & $-3.64^{\mathrm{a}}$ & $-3.24^{\mathrm{a}}$ & -0.78 & $-3.76^{\mathrm{a}}$ & $-3.90^{\mathrm{a}}$ & -1.88 \\
\hline
\end{tabular}

Notes: ${ }^{a}$ denotes significant at $1 \%$ level.

Cointegration among variables is tested using the first and secondgenerations as presented in Tables 7 and 8 . The results of the first-generation using Pedroni's (1999; 2004) panel cointegration tests are reported in Table 7. There are seven different cointegration statistics proposed by Pedroni to capture the withinand between-dimension effects in the panel. It can be classified in two categories which are within dimension and between dimension. From the results, five of the seven panel cointegration tests for Model 1 and Model 2 indicate that the null hypothesis of no cointegration is rejected at $1 \%$ and $5 \%$ significance levels. Table 8 reports the findings from the Westerlund's (2007) panel cointegration tests, which is allow for cross-sectional dependence. The empirical results indicate that $G_{\tau}$ and $P_{\tau}$ test statistics reject the null hypothesis of no cointegration at $1 \%$, $5 \%$ and $10 \%$ significance levels for both models, only that the specification is without trend. Both $P_{\alpha}$ and $P_{\tau}$ test statistics are significant at $1 \%$ and $5 \%$ in both models. We focus on the $P_{\alpha}$ and $P_{\tau}$ test statistics since, according to Westerlund (2007), those statistics have the highest power and are the most robust to crosssectional correlation. Therefore, the evidence from these panel tests supports the 
presence of a cointegrating relationship among foreign direct investment, financial development, inflation, and economic development in ASEAN-5 countries.

Table 7

Pedroni (2004) panel cointegration results

\begin{tabular}{lcc}
\hline & Model 1: & Model 2: \\
& (FDI, DCPS, CPI, GDP) & (FDI, PC, CPI, GDP) \\
\hline Within dimension & & \\
Panel $v$ & 1.026 & 1.195 \\
Panel $\rho$ & $-1.699^{* *}$ & $-1.904^{* *}$ \\
Panel PP & $-4.264^{* * *}$ & $-4.350^{* * *}$ \\
Panel ADF & $-2.318^{* *}$ & $-2.393^{* * *}$ \\
Between dimension & & \\
Group $\rho$ & -0.77 & -1.031 \\
Group PP & $-4.496^{* * *}$ & $-4.546^{* * *}$ \\
Group ADF & $-2.305^{* *}$ & $-2.322^{* *}$ \\
\hline
\end{tabular}

Notes: (i) Trend Assumption: No deterministic trend.

(ii) Fixed lag length selection at 1.

(iii) $* * *$ and $* *$ indicates the coefficient significant at the $1 \%$ and $5 \%$ level respectively.

Table 8

Westerlund (2007) panel cointegration results

\begin{tabular}{|c|c|c|c|c|}
\hline \multirow{2}{*}{ Statistics } & \multicolumn{2}{|c|}{ Without trend } & \multicolumn{2}{|c|}{ With trend } \\
\hline & Value & $p$-value & Value & $p$-value \\
\hline \multicolumn{5}{|c|}{ Model 1: FD = Domestic credit to private sector } \\
\hline$G_{\tau}$ & -2.290 & 0.103 & -2.769 & 0.433 \\
\hline$G_{\alpha}$ & -8.116 & 0.457 & -8.112 & 0.981 \\
\hline$P_{\tau}$ & $-5.058^{*}$ & 0.053 & -5.546 & 0.484 \\
\hline$P_{\alpha}$ & $-12.533 * * *$ & 0.002 & -13.680 & 0.329 \\
\hline \multicolumn{5}{|c|}{ Model 2: FD = Private credit to deposit money } \\
\hline$G_{\tau}$ & $-2.452 *$ & 0.052 & -2.742 & 0.461 \\
\hline$G_{\alpha}$ & -8.862 & 0.353 & -7.020 & 0.991 \\
\hline$P_{\tau}$ & $-5.912 * *$ & 0.012 & -6.113 & 0.260 \\
\hline$P_{\alpha}$ & $-16.337 * * *$ & 0.000 & -11.098 & 0.623 \\
\hline
\end{tabular}

Notes: (i) Fixed lag length selection at 1.

(ii) $* * *$ and $*$ indicates the coefficient significant at the $1 \%$ and $10 \%$ level respectively. 
Table 9 reports that Models 1-2 estimates the linear and nonlinear relations between financial development and real GDP per capita for the long-run estimation by using FMOLS. Long-run covariance estimates pre-whitening with lag 1, where the automatic bandwidth selection is based on Newey-West fixed bandwidth and Bartlett kernel. In the linear specification, the relationship between financial development and FDI is not significant in both models. However, in contrast, our result is consistent with both proxies of the financial development, which has a significant impact on the FDI in the nonlinear relationship. The nonlinear U-shaped relationship between financial development and FDI inflows has been proven where $\alpha_{1}$ and $\alpha_{2}$ (Equation 3 ) is negative and positive, respectively indicating that increased finance is related to more FDI inflows. We obtain an empirical support as we expected in earlier discussions for the presence of antiKuznet curve or U-shaped in model 1-2 as indicated by the negatively significant coefficient of financial development and significantly positive coefficient of financial development squared.

Our result shows that the negative effect of low level of financial development below the threshold level (70 points) is related to FDI. This result concurred with the findings by Yohanna (2013) who found that the underdeveloped financial sector was negatively affected on FDI inflows. The higher financial development reflects high financial strength in that particular country. The strength of financial development attracts the inflows of FDI seeking for financial resource in the host country to assist day-to-day business. Foreign investors are thus attracted to expand their business into countries with financial strength. Above the threshold value at 70 points, financial development influences have positive impact on FDI inflows. Based on model 1 (DCPS) in the quadratic specification, the financial development threshold point is 73.38 point $(-0.587 /$ $(0.004 \times 2))$ and in model $2(\mathrm{PCDM}), 78.13 \%$ point $(-0.625 /(0.004 \times 2))$. The result showed that the DCPS exceeded the threshold point at $50 \%$ quantile to facilitate FDI inflows, while for PCDM the threshold was at $75 \%$ quantile (Table 2).

When financial development in the ASEAN-5 countries exceeded the threshold level at $70 \%$ of GDP, FDI inflows increased into the region in a nonlinear relationship. Our results however differed from those of previous studies which examined the relationship between financial development and FDI inflows based on linear model (di Giovanni, 2005; Stein \& Daude, 2007; Mohamed \& Sidiropoulos, 2010). Alfaro et al. (2004) suggested that the host countries with well-developed financial market benefited FDI. In addition, financial integration reduced information costs and encouraged foreign firms to invest in the ASEAN-5 countries. 
Table 9

Panel FMOLS long-run estimates (Dependent variable: Foreign Direct Investment)

\begin{tabular}{|c|c|c|c|c|}
\hline \multirow[b]{2}{*}{ Variables } & \multicolumn{2}{|c|}{ Linear Model } & \multicolumn{2}{|c|}{ Quadratic Model } \\
\hline & $\begin{array}{c}\text { Model 1: } \\
F D=D C P S\end{array}$ & $\begin{array}{c}\text { Model } 2: \\
F D=P C D M\end{array}$ & $\begin{array}{c}\text { Model 1: } \\
F D=D C P S\end{array}$ & $\begin{array}{c}\text { Model 2: } \\
F D=P C D M\end{array}$ \\
\hline GDP & 0.001 & 0.002 & 0.001 & 0.002 \\
\hline CPI & $-0.345 * * *$ & $-0.317 * *$ & $-0.478 * * *$ & $-0.437 * * *$ \\
\hline FinDev & 0.044 & 0.014 & $-0.587 * *$ & $-0.625 * * *$ \\
\hline FinDev square & - & - & $0.004 * * *$ & $0.004 * * *$ \\
\hline Threshold value & & & 73.38 & 78.13 \\
\hline
\end{tabular}

Notes: (i) Panel method using grouped estimation.

(ii) $* * *, * *$ indicates the coefficient significant at the $1 \%$ and $5 \%$ level respectively.

The GDP, a parameter representing market size, also provides attraction to foreign investors who prefer market-seeking in order to locate their production site to the host countries. The parameter however, is not significantly related to FDI inflows in the ASEAN-5 countries (in long-run estimation) in contradiction to findings by Yohanna (2013). But in the short-run dynamic, GDP is Granger cause FDI directly (Table 10). The price for goods and services is however negatively influence FDI inflows due to the burden ensuing from increment in production cost. An increase in price of goods and services will reflect the increment of production cost that can reduce the potential profitability for foreign firms. In addition, an increase in price will reduce the purchasing power parity of citizens in the host country, and as a result, the innovate products produced by foreign firms may become unmarketable or over-supplied in the host country. This situation tend to reduce foreign investors' attraction to invest in the host country particularly for those with 'market-seeking' objective.

Table 10 reports the Granger causality result based on the panel VECM model with four variables in each model. The estimation is conducted using two models corresponding to two financial development measures. The lag length is fixed at 1 . For both models, error correction term is negative and significant for the FDI equation, suggesting that there is a long run relationship when the FDI is dependent variable.

The short-run causality channels from the panel VECM estimations are summarised in Figure 1. As shown in Figure 1, there is a unidirectional causal effect running from real GDP per capita to domestic credit to private sector, domestic credit to private sector to inflation, and real GDP per capita to inflation. However, there exists a broken link between the domestic credit to private sector, 
private credit to deposit money and FDI in short term. There are two bidirectional causal effect exists between the FDI and real GDP per capita, and private credit to deposit money and real GDP per capita. Private credit to deposit money effect indirectly on FDI via GDP because the private credit support the money to be hold among the citizen as well as market size is growing. In view of this, the findings tend to support Alfaro et al. $(2004 ; 2009)$ in the direction of the FDI-growth nexus in the host country, and also Levine (2005) in the finance-growth nexus. The error-correction terms presented in the last column of all models demonstrate that the burden of the short-run endogenous adjustment (to long-run trends) to bring the system back to its long-run equilibrium is borne by the FDI, inflation and real GDP per capita.

Table 10

Granger causality based on panel VECM estimations

\begin{tabular}{|c|c|c|c|c|c|}
\hline \multirow{3}{*}{$\begin{array}{l}\text { Dependent } \\
\text { Variable }\end{array}$} & \multicolumn{4}{|c|}{ Independent Variables } & \multirow{3}{*}{$\begin{array}{c}\mathrm{ECT}_{t-1} \\
\text { Coefficient } \\
(t \text {-Statistics })\end{array}$} \\
\hline & $\Delta \mathrm{FDI}$ & $\Delta$ FinDev & $\Delta \mathrm{CPI}$ & $\Delta \mathrm{GDP}$ & \\
\hline & \multicolumn{4}{|c|}{ (Wald F -Statistics) } & \\
\hline \multicolumn{6}{|c|}{ Model 1: FD = Domestic credit to private sector } \\
\hline$\triangle F D I$ & - & 0.144 & 0.232 & $19.795^{* * *}$ & $\begin{array}{c}-0.728 \\
(-7.019)^{* * *}\end{array}$ \\
\hline$\Delta$ FinDev & 0.028 & - & 1.240 & $6.102 * * *$ & $\begin{array}{c}0.000 \\
(0.190)\end{array}$ \\
\hline$\triangle C P I$ & 0.314 & $2.574 *$ & - & $2.415^{*}$ & $\begin{array}{c}0.001^{* *} \\
(2.468)\end{array}$ \\
\hline$\triangle G D P$ & $53.125 * * *$ & 1.634 & 0.856 & - & $\begin{array}{c}0.018 \\
(7.839)^{* * *}\end{array}$ \\
\hline \multicolumn{6}{|c|}{ Model 2: $\mathrm{FD}=$ Private sector to deposit money } \\
\hline$\triangle F D I$ & - & 0.129 & 0.228 & $16.748 * * *$ & $\begin{array}{c}-0.727 \\
(-7.010)^{* * *}\end{array}$ \\
\hline$\Delta$ FinDev & 0.065 & - & 1.707 & $11.594 * * *$ & $\begin{array}{c}-0.002 \\
(-0.716)\end{array}$ \\
\hline$\triangle C P I$ & 0.313 & 0.779 & - & 1.088 & $\begin{array}{c}-0.001 \\
(2.182)^{* *}\end{array}$ \\
\hline$\triangle G D P$ & $47.773 * * *$ & $4.66^{* *}$ & 1.162 & - & $\begin{array}{c}0.017 \\
(7.737)^{* * *}\end{array}$ \\
\hline
\end{tabular}

Notes: (i) FDI: foreign direct investment; FinDev: financial development; CPI: consumer price index; GDP: real GDP per capital.

(ii) ECT, error-correction term.

(iii) $* * *, * *$ and $*$ denotes significant at $1 \%, 5 \%$ and $10 \%$ level. t-statistic in parentheses. 


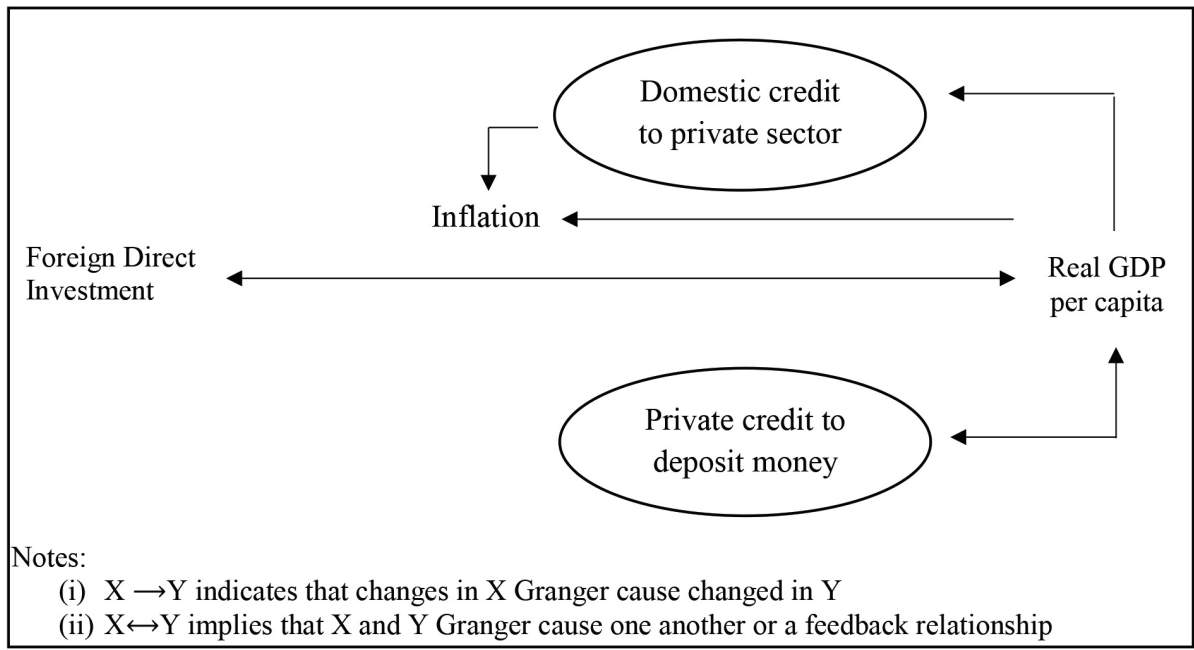

Figure 1. Short run causal channels summarised from panel VECM

\section{CONCLUSION}

This study examines the relationship between the financial development, inflation and GDP to FDI in ASEAN-5 countries from 1980 to 2013. In particular, we aim to investigate whether or not the financial development has a nonlinear relationship with FDI. It is important to understand how the financial development affects FDI. The empirical analyses are based on the first- and second-generation panel cointegration to test for long-run and short-run dynamic relationship. The secondgeneration panel cointegration test which include cross-dependence among ASEAN-5 economic integration is employed (Westerlund, 2007).

Our results demonstrated that there exist cross-sectional dependence among the ASEAN-5 countries which thus supports the argument by Guerin (2005) who showed that there is a role for geographic influence on financial integration as well as on FDI. Economic integration has a direct effect on internationalisation by reducing transaction costs and partial information costs (Guerin, 2005). Foreign enterprises have extended their business activities in ASEAN countries and become regional players. Financial integration among the ASEAN-5 countries strengthened financial development as well as ease transaction activities among the regional players. Economic growth among the ASEAN-5 countries encompass various aspects including business, trading, tourism, foreign skilledlabour movement in the region, which encouraged the positive spill-overs among 
the countries. An increase in price of goods and services among the ASEAN-5 will be reflected in the regional price chain.

The existence of cross-sectional dependency shown in this study supported the efforts for ASEAN-5 financial integration. This integration in the ASEAN Economic Community (AEC) Blueprint 2025, will strengthen financial institutions, enhance commitment in implementation and in monitoring and evaluation of finance. Moreover, ASEAN seeks to achieve a well-integrated and smoothly functioning ASEAN region financial system, characterised by more liberalised capital account regime and inter-linked capital markets. Strengthening financial integration as well as financial market infrastructure are therefore aimed at facilitating intra-ASEAN trade and investment by increasing the role of ASEAN indigenous banks, and augmenting integrated insurance and capital markets leading to safe, cost-efficient and more connected regional economy.

The empirical results demonstrate that there is strong evidence in favour of a long-run relationship among FDI, financial development, inflation and real GDP per capita. In the long-run estimation using FMOLS, there exists a nonlinear relationship between both domestic credit to private sector and private credit by the deposit money to FDI in the quadratic model. The nonlinearity between both financial developments on the FDI are anti-Kuznets or U shape. However, the contribution of financial development to the FDI exist in the long run, but not in the short run. In terms of policy implications, these findings suggest that it is important for the ASEAN-5 economies to increase financial development, in accordance with financial integration in the AEC Blueprint 2015. Based on the findings from the quadratic model, financial development contributed towards promoting FDI after a certain level at above 70 point. In general, it can be concluded that countries would need to surpass the median financial development score in order for the FDI to get the benefit from financial development. The attraction of FDI inflows is an important goal of the AEC and largely conditional to the success of the ASEAN-5 integration efforts. Hence, this study suggests that an increases in financial development encourage more FDI inflows into the ASEAN-5 countries.

\section{ACKNOWLEDGEMENTS}

We are grateful for the financial support from the Fundamental Research Grant Scheme (FRGS), Ministry of Higher Education (grant no: FRGS/2/2014/SS05/ KUIS/03/1). 


\section{REFERENCES}

Alfaro, L., Chanda, A., Kalemli-Ozcan, S., \& Sayek, S. (2004). FDI and economic growth: The role of local financial markets. Journal of International Economics, 64(1), 89-112. https://doi.org/10.1016/S0022-1996(03)00081-3

Alfaro, L., Kalemli-Ozcan, S., \& Sayek, S. (2009). FDI, productivity and financial development. The World Economy, 32(1), 111-135. https://doi.org/10.1111/ j.1467-9701.2009.01159.x

Bekana, D. M. (2016). Determinants of foreign direct investment in Ethiopia; time series evidence from 1991-2013. The Journal of Developing Areas, 50(1), 141-155. https://doi.org/10.1353/jda.2016.0002

Benáček, V., Lenihan, H., Andreosso-O’Callaghan, B., Michalíková, E., \& Kan, D. (2014). Political risk, institutions and foreign direct investment: How do they relate in various European countries? The World Economy, 37(5), 625-653. https://doi. org/10.1111/twec. 12112

Blonigen, B. A., \& Piger, J. (2014). Determinants of foreign direct investment. Canadian Journal of Economics/Revue canadienne d'économique, 47(3), 775-812. https:// doi.org/10.1111/caje.12091

Campbell, J. Y., \& Perron, P. (1991). Pitfalls and opportunities: What macroeconomists should know about unit roots. NBER Macroeconomics Annual, 6, 141-201. https://doi.org/10.1086/654163

Çeviş, I., \& Çamurdan, B. (2007). The economic determinants of foreign direct investment in developing countries and transition economies. The Pakistan Development Review, 46(3), 285-299.

Dauti, B. (2015). Determinants of foreign direct investment in transition economies, with special reference to Macedonia: Evidence from Gravity Model. South East European Journal of Economics and Business, 10(2), 7-28. https://doi. org/10.1515/jeb-2015-0007

Dunning, J., \& Robson, P. (eds.). (1988). Multinationals and the European community. Oxford: Blackwell.

di Giovanni, J. (2005). What drives capital flows? The case of cross-border M\&A activity and financial deepening. Journal of International Economics, 65, 127-149. https://doi.org/10.1016/j.jinteco.2003.11.007

Engle, R. F., \& Granger, C. W. (1987). Co-integration and error correction: Representation, estimation, and testing. Econometrica, 55(2), 251-276. https://doi. org $/ 10.2307 / 1913236$

Guerin, S. S. (2005). The role of geography in financial integration: Foreign direct investment. LLEE working paper no. 36, LUISS Lab of European Economics, Rome.

Henry, K., Saadatmand, Y., \& Toma, M. (2015). Determinants of Foreign Direct Investment in Central and South America and the Caribbean Islands. Journal of International Business Research, 14(1), 58.

Im, K., Pesaran, H., \& Shin, Y. (1997). Testing for unit roots in heterogeneous panels. DAE working paper Amalgamated Series no. 9526. Cambridge, University of Cambridge Press. 
Johnson, A. (2006). FDI inflows to the transition economies in Eastern Europe: Magnitude and determinants. Working Paper Series in Economics and Institutions of Innovation No. 59, CESIS - Centre of Excellence for Science and Innovation Studies (CESIS), Royal Institute of Technology.

Kao, C., \& Chiang, M. H. (2000). On the estimation and inference of a cointegrated regression in panel data. In B. Baltagi (ed.), Nonstationary panels, panel cointegration, and dynamic panels (Advances in Econometrics) (pp. 161-178). Amsterdam: JAI Press.

Kao, C., \& Chiang, M. H. (2001). On the estimation and inference of a cointegrated regression in panel data. In Baltagi, B. H., Fomby, T. B., \& Hill, R. C. (eds.) Nonstationary panels, panel cointegration, and dynamic panels (pp. 179-222). United Kingdom: Emerald Group Publishing Limited.

Law, S. H., \& Singh, N. (2014). Does too much finance harm economic growth? Journal of Banking \& Finance, 41, 36-44. https://doi.org/10.1016/j.jbankfin.2013.12.020

Levin, A., Lin, C. F., \& Chu, C. S. J. (2002). Unit root tests in panel data: Asymptotic and finite-sample properties. Journal of Econometrics, 108(1), 1-24. https://doi. org/10.1016/S0304-4076(01)00098-7

Levine, R. (2005). Finance and growth: Theory and evidence. Handbook of Economic Growth, 1, 865-934.

Maddala, G. S., \& Wu, S. (1999). A comparative study of unit root tests with panel data and a new simple test. Oxford Bulletin of Economics and statistics, 61(S1), 631-652. https://doi.org/10.1111/1468-0084.61.s1.13

Mateev, M. (2009). Determinants of foreign direct investment in Central and Southeastern Europe: New empirical tests. Oxford Journal, 8(1), 133-149.

Mohamed, S. E., \& Sidiropoulos, M. G. (2010). Another look at the determinants of foreign direct investment in MENA countries: An empirical investigation. Journal of Economic Development, 35(2), 75.

Pattayat, S. S. (2016). Examining the determinants of FDI inflows in India. Theoretical and Applied Economics, 22(2), 225-238.

Pedroni, P. (1999). Critical values for cointegration tests in heterogeneous panels with multiple regressors. Oxford Bulleting Economic Statistics, 61(1), 653-670.

Pedroni, P. (2000). Fully modified OLS for heterogeneous cointegrated panels. Advances in Econometrics, 15, 93-130.

Pedroni, P. (2001). Purchasing power parity tests in cointagrated panels. The Review of Economics and Statistics, 83(4), 727-731.

Pedroni, P. (2004). Panel cointegration: Asymptotic and finite sample properties of pooled time series tests with an application to the PPP hypothesis. Econometric Theory, 20,597-625.

Pesaran, M. H. (2004). General diagnostic tests for cross section dependence in panels. Cambridge Working Papers in Economics No. 0435, University of Cambridge. https://doi.org/10.17863/CAM.5113

Pesaran, M. H. (2007). A simple panel unit root test in the presence of cross-section dependence. Journal of Applied Econometrics, 22(2), 265-312. https://doi. org/10.1002/jae.951 
Plummer, M. G., \& Cheong, D. (2009). FDI effects of ASEAN integration. Région et Développement, 29(6), 50-67.

Rad, S. S. E., Embong, Z., Mohd-Saleh, N., \& Jaffar, R. (2016). Financial information quality and investment efficiency: Evidence from Malaysia. Asian Academy of Management Journal of Accounting \& Finance, 12(1), 129-151.

Samargandi, N., Fidrmuc, J., \& Ghosh, S. (2015). Is the relationship between financial development and economic growth monotonic? Evidence from a sample of middleincome countries. World Development, 68, 66-81. https://doi.org/10.1016/j. worlddev.2014.11.010

Sankaran, C. (2015). An analysis of the determinants of FDI inflows: The case of the Dominican Republic. IUP Journal of Applied Economics, 14(1), 47.

Sawalha, N., Mazouz, A., \& Pellet, P. (2013). Foreign direct investment inflows and determinants in selected developed, developing, and underdeveloped countries with limited resources. International Journal of Business \& Economics Perspectives, 8(1), 76-92.

Stein, E., \& Daude, C. (2007). Longitude matters: Time zones and the location of foreign direct investment. Journal of International Economics, 71, 96-122. https://doi. org/10.1016/j.jinteco.2006.01.003

Westerlund, J. (2007). Testing for error correction in panel data. Oxford Bulletin of Economics and Statistics, 69(6), 709-748. https://doi.org/10.1111/j.14680084.2007.00477.x

Yohanna, P. (2013). Macroeconomic determinants of foreign direct investment and economic transformation in Nigeria, 1981-2010: An empirical evidence. Insight on Africa, 5(1), 55-82. https://doi.org/10.1177/0975087813512055

Zulfiu, M. (2008). Determinants of foreign direct investment in transition economies: With particular reference to Macedonia's performance. FIW working paper No. 19. 